\title{
Integrated model of moulting and feeding of Antarctic krill Euphausia superba off South Georgia
}

\author{
D. J. Morris \\ British Antarctic Survey, Natural Environment Research Council, High Cross, Madingley Road, Cambridge CB3 0ET, \\ United Kingdom
}

\begin{abstract}
The vertical and temporal distribution of krill undergoing moult and the physiological relations between feeding activity and moulting behaviour of Antarctic krill Euphausia superba Dana are used in a model of ecological aspects of moulting. Two periods per day of peak moulting activity occur in krill off South Georgia: in the afternoon and early night. This suggests the existence of 2 strategies for fuelling the post-moult hardening of the exoskeleton. The temporal and vertical distribution of krill undergoing moult also indicates the importance of both light and predation as potential factors affecting moulting behaviour. It is suggested that this may account for published observations, both in the field and in the laboratory, of synchronous moulting in krill. The consistency of the pattern of moulting activity is examined for each of the $6 \mathrm{~d}$ of the study period, and derived intermoult periods and rhythmicities in moulting are discussed in terms of the homogeneity of the population studied. These observations and previously published detailed models for the feeding activity - in relation to water depth and time of day - of E. superba off South Georgia are synthesised into a single model that links feeding, swarming, vertical migration, environmental variables and moulting. Published energy requirements and the levels of plant pigment found in the components of the alimentary tract of krill are also integrated with published egestion rates, to derive estimates of a tumover time for the alimentary tract and an assimilation efficiency.
\end{abstract}

\section{INTRODUCTION}

The feeding behaviour of Antarctic krill Euphausia superba Dana has been the subject of much study both in field and laboratory. Field studies have indicated that feeding is one element in the complex interaction between nutritional requirements, swarming behaviour and vertical migration (Pavlov 1969, Gubsch 1979, Kalinowski \& Witek 1980, Morris et al. 1983, Antezana \& Ray 1984). No clear pattern has emerged within these relations that could be applicable to the wide range of environments occupied by krill and it is likely that krill adapt to the local oceanic conditions. Laboratory work on feeding by krill has provided outlines of potential feeding mechanisms, filtration, ingestion and egestion rates, effects of chlorophyll levels and swarming (Kils 1981, Antezana et al. 1982 . Kato et al. 1982, Antezana \& Ray 1984, Hamner et al. 1983, McClatchie \& Boyd 1983, Morris 1984). These have been summarised and incorporated into an energy budget by Clarke \& Morris (1983) in a review of the physiological ecology of krill. The literature gives a detailed, though confused, picture of the feeding behaviour of krill, because laboratory data were collected from krill held under conditions that differ from the natural environment and field data were subject to the operating constraints of oceanic shipboard research programmes.

An analysis of feeding of Euphausia superba also permits an examination of the patterns of moulting behaviour because of the close physiological links between feeding and moulting, particularly the emptying of the alimentary tract prior to moult (Mauchline \& Fisher 1969, Ikeda et al. 1984). Furthermore, observations on the hardness or softness of the exoskeleton can also be used because a soft exoskeleton indicates the very recent occurrence of moulting (Buchholz 1982 Morris \& Keck 1984). An histological analysis of the moult stages of krill in various feeding states further elucidates the physiological relations between feeding and moulting as well as improving our understanding of the ecology of moulting in E. superba. 
An intensive $6 \mathrm{~d}$ field study of feeding in Euphausia superba off South Georgia in January 1982 generated a simple model for feeding (Morris \& Ricketts 1984), wherein the level of stomach fullness was affected only by the time of day. The fullness of the hepatopancreas and gut were affected only by the level of stomach fullness and depth did not affect the level of fullness in any component of the alimentary tract. This model was related to the environmental parameters measured and the vertical distribution of krill by Morris et al. (1984).

Of the population sampled, $70 \%$ of the krill were classified as feeding. The remainder were either undergoing moult or believed to be involved in moultrelated feeding activity. In this paper these relations between feeding and moulting are examined and synthesised into simple models for the moulting of krill off South Georgia. The models of feeding and moulting ecology are summarised and interpreted in the light of calculated turnover times for the contents of the alimentary tract and the non-random timing of moulting in the population sampled. An integrated model is proposed specifically for krill off South Georgia at times outside the major phytoplankton bloom as it is likely that different environmental conditions will affect the interactions between feeding, moulting, swarming and vertical migration both off South Georgia and in other areas.

\section{MATERIALS AND METHODS}

The sampling methods and procedures used to analyse the krill caught were described by Morris \& Ricketts (1984). Krill were sampled along a transect by Rectangular Midwater Trawl from 4 depth ranges, 6 times a day for $6 \mathrm{~d}$. The amount of food in the alimentary tract was estimated visually and the presence of a soft exoskeleton noted for $9421 \mathrm{krill}$. A subsample of the krill caught ( $n=186$ ) were further assessed for moult stage by histological examination of the uropods under a phase contrast microscope according to the method described by Buchholz (1982).

The detailed series of moult stages outlined by Buchholz (1982) for Euphausia superba have been reduced to the categories described below, with the following definitions: intermoult: late post-moult, intermoult and early pre-moult stages (when the majority of krill will be feeding); moult: late pre-moult, ecdysis and early post-moult stages (when krill are undergoing moult related feeding activity or actual ecdysis); ecdysis: immediate pre-moult, shedding of the exoskeleton and immediate post-moult stages (when krill are in the actual process of moulting and will have either an empty alimentary tract or a soft exoskeleton or both).

Throughout this examination of the physiological relations between feeding and moulting it is assumed that the following sequence of events occurs during moulting: krill empty the alimentary tract whilst the exoskeleton is hard by a cessation of feeding; ecdysis is externally characterised by a soft exoskeleton which hardens post-moult; the hardening of the exoskeleton may occur prior to the recommencement of feeding, or feeding may recommence prior to the complete hardening of the exoskeleton. This is based upon observations of post-moult krill with either an empty alimentary tract and a hard exoskeleton, or with a soft exoskeleton and food present in the alimentary tract (krill with empty alimentary tracts were either immediate pre-moult or immediate or early post-moult whilst krill with soft exoskeletons were in ecdysis or in immediate post-moult).

\section{RESULTS}

\section{Ecology of moulting}

Moulting in Euphausia superba can be broadly outlined by examining the occurrence (with respect to depth and time of day caught) of individuals in conditions known to be directly related to moult phase and those actually undergoing ecdysis, i.e. krill with an empty alimentary tract or a soft exoskeleton. Total numbers of krill in each of the 3 possible conditions (empty/hard, empty/soft, food present/soft) caught during each $4 \mathrm{~h}$ time period were compared with the expected number from all krill caught (Table 1). Data were pooled from $6 \mathrm{~d}$ of sampling and from all depths. Krill with a hard exoskeleton and an empty alimentary tract were split into 2 assumed moult stages on the basis of histological analysis (of the 26 empty/hard krill analysed, $12 \%$ were in immediate pre-moult and $88 \%$ in immediate post-moult). The krill were not evenly distributed in the catches throughout the $24 \mathrm{~h}$ $\left(\chi^{2}: \mathrm{p} \ll 0.001, \quad \mathrm{df}=5, \mathrm{n}=1086\right)$. Major differences occur where more moulting - particularly empty/soft krill were caught than expected in the periods 1200 to $1600 \mathrm{~h}$ and 2000 to $2400 \mathrm{~h}$. Markedly fewer moulting krill than expected were caught between 0400 and $1200 \mathrm{~h}$.

The broad differences in the occurrence of moulting krill during the $24 \mathrm{~h}$ period were further analysed in relation to depth, as well as time of day, for krill that were empty/hard, empty/soft and those with a soft exoskeleton and food in the alimentary tract. Because of the low numbers of samples in some depth/time cells, the data were analysed simply by time (all depths pooled) and by depth (all times pooled). Any significant differences were further examined by comparing the numbers of krill observed and expected for the 24 depth/time cells. Table 2 shows observed and 
Table 1. Euphausia superba. Number of specimens in each moult stage (defined by emptiness of alimentary tract and exoskeleton condition) for each time of day. Bar: darkness; numbers in parentheses: expected values for the number of krill caught

\begin{tabular}{|c|c|c|c|c|c|c|c|c|}
\hline \multirow{2}{*}{$\begin{array}{l}\text { Alimentary tract/ } \\
\text { Exoskeleton condition }\end{array}$} & \multirow[t]{2}{*}{ Assumed moult stage } & \multicolumn{3}{|c|}{ Local time } & \multirow[b]{2}{*}{$20-24$} & \multirow[b]{2}{*}{$24-04$} & \multirow[b]{2}{*}{$04-08$} & \multirow[b]{2}{*}{ Total } \\
\hline & & $08-12$ & $12-16$ & $16-20$ & & & & \\
\hline Empty/hard & Immediate pre-moult & 1 & 12 & 12 & 0 & 2 & 1 & 28 \\
\hline Empty/soft & $\begin{array}{l}\text { Moult or immediate } \\
\text { post-moult }\end{array}$ & 4 & 223 & 29 & 252 & 57 & 8 & 573 \\
\hline Empty/hard & Early post-moult & 4 & 91 & 93 & 0 & 18 & 12 & 218 \\
\hline Food present/soft & Early post-moult & 11 & 34 & 65 & 64 & 78 & 15 & 267 \\
\hline Total & & $\begin{array}{c}20 \\
(121)\end{array}$ & $\begin{array}{c}360 \\
(161)\end{array}$ & $\begin{array}{c}199 \\
(139)\end{array}$ & $\begin{array}{l}316 \\
(218)\end{array}$ & $\begin{array}{l}155 \\
(277)\end{array}$ & $\begin{array}{c}36 \\
(170)\end{array}$ & $\begin{array}{c}1086 \\
(1086)\end{array}$ \\
\hline
\end{tabular}

expected numbers of krill caught with an empty alimentary tract and a hard exoskeleton; $\chi^{2}$ tests for these data are significant (time, $\mathrm{p} \ll 0.001$, df $=5$; depth, $\mathrm{p}<0.001$, df $=3, \mathrm{n}=246$ ). The depth/time cells contributing to the majority of the difference are 1200 to $1600 \mathrm{~h}$ below the thermocline and 1600 to $2000 \mathrm{~h}$ below $100 \mathrm{~m}$, with approximately 6 times more krill than expected.

Krill with an empty alimentary tract and a soft exoskeleton also show significant differences between the observed and the expected numbers of krill caught (time, $\quad \mathrm{p} \ll 0.001, \quad \mathrm{df}=5 ; \quad$ depth, $\quad \mathrm{p}<0.001$, $\mathrm{df}=3, \mathrm{n}=573$ ). Five depth/time cells account for the majority of the difference; 1200 to $1600 \mathrm{~h}$ above and below the thermocline and 2000 to $2400 \mathrm{~h}$ above and below the thermocline and below $100 \mathrm{~m}$; where the numbers of krill were between 2 and 5 times those expected.

Krill with food in the alimentary tract but with a soft exoskeleton were also distributed in a significantly different manner from that expected (time, $\mathrm{p} \ll 0.001$. $\mathrm{df}=5 ;$ depth, $\mathrm{p}<0.01, \mathrm{df}=3, \mathrm{n}=267$ ). There are 2 depth/time cells with numbers of krill 2 to 3 times higher than expected: 1600 to 2000 h below $100 \mathrm{~m}$ and 2400 to $0400 \mathrm{~h}$ above the thermocline.

The uneven distributions of those krill directly associated with moulting indicate that moulting does not occur randomly with respect to depth or time of day. Those depth/time cells that contribute most to the differences between observed and expected values are summarised diagrammatically in Fig. 1. Krill classified as moulting occurred at all depths and all times but there were more krill that were empty/hard (assumed to be immediate pre-moult) caught in the period 1200 to $1600 \mathrm{~h}$ between 70 and $100 \mathrm{~m}$. This was accompanied by a large number of krill that were in ecdysis (empty/soft) between 10 and $100 \mathrm{~m}$ and by early postmoult krill (empty/hard) from 70 to $100 \mathrm{~m}$. Below $100 \mathrm{~m}$ in the period 1600 to $2000 \mathrm{~h}$, krill classed as early postmoult (food present/soft) occurred with krill classed as

Table 2. Euphausia superba. Number of specimens classed as empty/hard as a function of depth and time of day. Bar· darkness; numbers in parentheses: expected values for the number of krill caught

\begin{tabular}{|c|c|c|c|c|c|c|c|}
\hline $\begin{array}{l}\text { Depth range } \\
(\mathrm{m})\end{array}$ & $\begin{array}{l}\text { Local time } \\
08-12\end{array}$ & $12-16$ & $16-20$ & $20-24$ & $24-04$ & $04-08$ & Total \\
\hline $\begin{array}{l}\text { Surface } \\
0-3\end{array}$ & $\begin{array}{c}4 \\
(0)\end{array}$ & $\begin{array}{l}3 \\
(0)\end{array}$ & $\begin{array}{l}18 \\
(1)\end{array}$ & $\begin{array}{c}0 \\
(13)\end{array}$ & $\begin{array}{c}0 \\
(16)\end{array}$ & $\begin{array}{c}4 \\
(1)\end{array}$ & $\begin{array}{c}29 \\
(31)\end{array}$ \\
\hline $\begin{array}{l}\text { Above thermocline } \\
10-50\end{array}$ & $\begin{array}{c}0 \\
(8)\end{array}$ & $\begin{array}{c}21 \\
(13)\end{array}$ & $\begin{array}{c}8 \\
(9)\end{array}$ & $\begin{array}{c}0 \\
(13)\end{array}$ & $\begin{array}{c}2 \\
(16)\end{array}$ & $\begin{array}{c}6 \\
(11)\end{array}$ & $\begin{array}{l}37 \\
(69)\end{array}$ \\
\hline $\begin{array}{l}\text { Below thermocline } \\
70-100\end{array}$ & $\begin{array}{c}1 \\
(10)\end{array}$ & $\begin{array}{l}74 \\
(12)\end{array}$ & $\begin{array}{c}5 \\
(10)\end{array}$ & $\begin{array}{c}0 \\
(11)\end{array}$ & $\begin{array}{c}10 \\
(16)\end{array}$ & $\begin{array}{c}1 \\
(13)\end{array}$ & $\begin{array}{l}91 \\
(72)\end{array}$ \\
\hline $\begin{array}{l}\text { Below } 100 \mathrm{~m} \\
100-150\end{array}$ & $\begin{array}{c}0 \\
(9)\end{array}$ & $\begin{array}{c}5 \\
(11)\end{array}$ & $\begin{array}{l}74 \\
(13)\end{array}$ & $\begin{array}{c}0 \\
(13)\end{array}$ & $\begin{array}{c}8 \\
(16)\end{array}$ & $\begin{array}{c}2 \\
(13)\end{array}$ & $\begin{array}{r}89 \\
(75)\end{array}$ \\
\hline Total & $\begin{array}{c}5 \\
(27)\end{array}$ & $\begin{array}{l}103 \\
(36)\end{array}$ & $\begin{array}{l}105 \\
(32)\end{array}$ & $\begin{array}{c}0 \\
(50)\end{array}$ & $\begin{array}{c}20 \\
(64)\end{array}$ & $\begin{array}{l}13 \\
(38)\end{array}$ & $\begin{array}{c}246 \\
(247)\end{array}$ \\
\hline
\end{tabular}




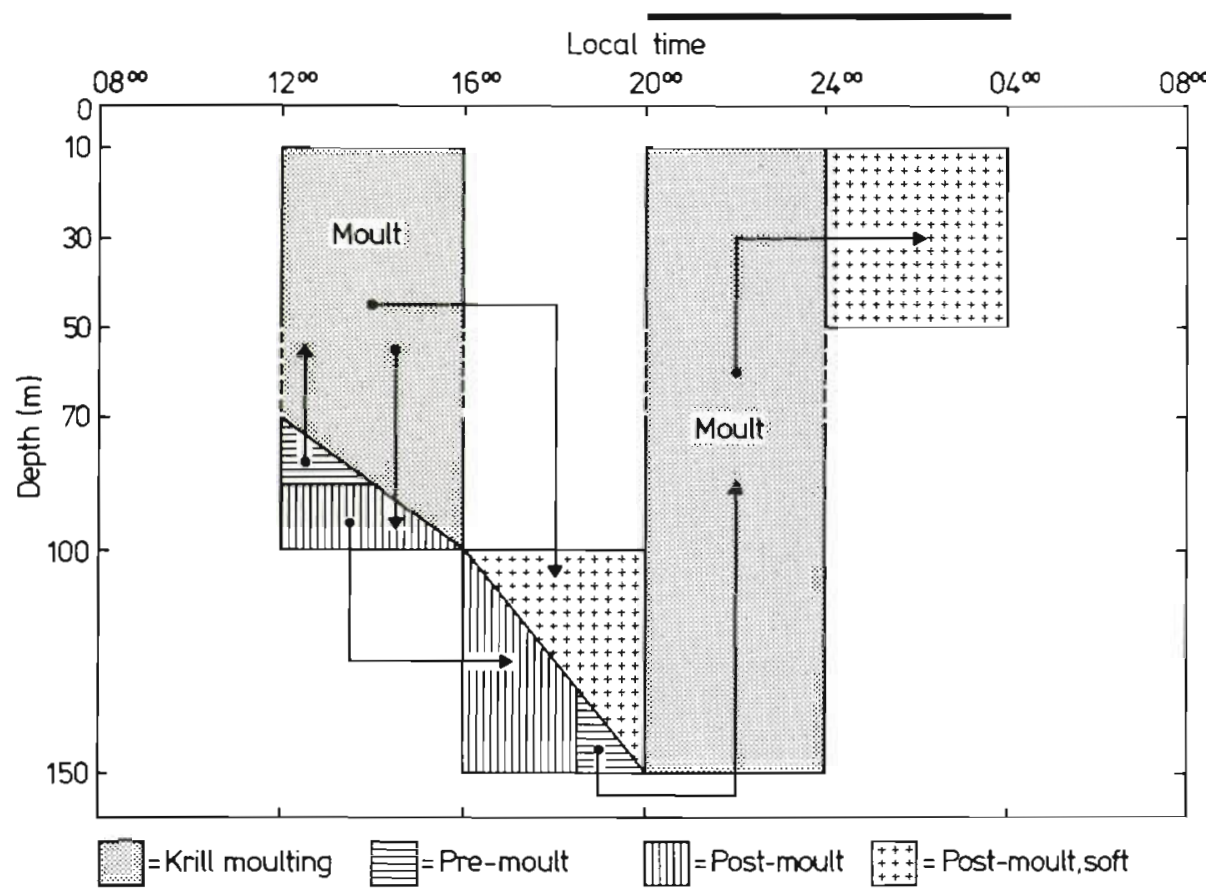

Fig. 1. Euphausia superba. Model of moulting behaviour of krill as a function of depth and time of day. Depth/time blocks allocated to pre-moult, moult and post-moult from the contribution to the major differences between observed and expected values in Tables 4 to 6

empty/hard. The latter krill may have been either immediate or early post-moult or immediate premoult. This is indicated by the subsequent occurrence of krill in ecdysis (empty/soft) from 2000 to $2400 \mathrm{~h}$, between 10 and $150 \mathrm{~m}$. From 2000 to $2400 \mathrm{~h}$, there were more krill classed as early post-moult (food present/ soft) caught between 10 and $50 \mathrm{~m}$ than expected.

\section{Pre- and post-moult feeding}

The 7 major feeding states described for Euphausia superba off South Georgia by Morris and Ricketts (1984) are grouped into 4 feeding categories ('empty', 'emptying or filling', 'full' and 'very full') on the basis of the total amounts of plant pigment in each state (Table 3). The feeding category 'full' accounted for $70 \%$ of the population and the vertical and temporal distribution of krill in this category are discussed in detail by Morris et al. (1984). A further $10 \%$ are directly involved in moulting, that is they have an 'empty' alimentary tract. Intermediate between these 2 categories is the 'emptying or filling' category: it is assumed that such individuals are in the early stages of pre-moult or post-moult. The feeding category 'very full' has approximately 3 times the amount of plant pigment in stomach and hepatopancreas found in the majority of krill but accounts for only $4 \%$ of the population. The differences between the 4 feeding categories are emphasised by the percentage of

Table 3. Euphausia superba. Mean, standard error and maximum amounts of total plant pigment for the 7 major feeding states found in krill (Morris \& Ricketts 1984). Values in parentheses: number of observations. Feeding states are grouped into 4 categories, with the \% of the population sampled in each category. Mean \% phaeophytin for stomach and hepatopancreas are given with the ratio of the amount of plant pigment in the stomach to the amount of pigment in the hepatopancreas

\begin{tabular}{|c|c|c|c|c|c|c|c|}
\hline $\begin{array}{l}\text { Feeding state } \\
\text { (stomach, hepato- } \\
\text { pancreas fullness) }\end{array}$ & $\begin{array}{l}\text { Total plant pigment } \\
\text { Mean } \pm \text { SE } \\
(n g)\end{array}$ & $\begin{array}{l}\text { Maxi- } \\
\text { mum } \\
(\mathrm{ng})\end{array}$ & $\begin{array}{l}\text { Feeding } \\
\text { cate- } \\
\text { gory }\end{array}$ & $\begin{array}{l}\% \text { of } \\
\text { the popu- } \\
\text { lation }\end{array}$ & $\begin{array}{c}\text { Mean \% } \\
\text { Sto- } \\
\text { mach }\end{array}$ & $\begin{array}{c}\text { phaeophytin } \\
\text { Hepato- } \\
\text { pancreas }\end{array}$ & $\begin{array}{c}\text { Hepatopancreas: } \text { stomach } \\
\text { ratio }\end{array}$ \\
\hline $\begin{array}{l}0.0 \\
0.1\end{array}$ & $\begin{array}{l}2.5 \pm 1.4(39) \\
2.4 \pm 1.0(8)\end{array}$ & $\begin{array}{r}28.9 \\
3.5\end{array}$ & Empty & 10 & 12.5 & 23.1 & 2.4 \\
\hline $\begin{array}{l}1.0 \\
2.0 \\
1.1\end{array}$ & $\begin{array}{l}14.0 \pm 5.9(8) \\
23.0 \pm 5.1(8) \\
32.2 \pm 7.1(40)\end{array}$ & $\begin{array}{r}25.6 \\
33.6 \\
113.1\end{array}$ & $\begin{array}{l}\text { Emptying } \\
\text { or } \\
\text { filling }\end{array}$ & 16 & 65.4 & 67.5 & 2.8 \\
\hline 2.1 & $58.3 \pm 6.3(96)$ & 164.4 & Full & 70 & 68.8 & 74.1 & 2.0 \\
\hline 2.2 & $151.0 \pm 26.9(40)$ & 487.4 & Very full & 4 & 59.4 & 74.1 & 8.2 \\
\hline
\end{tabular}


phaeopigment found in stomach and hepatopancreas; empty krill have a low percentage of phaeopigment whereas the other categories have a high percentage. In contrast, the ratio of amount of plant pigment in the hepatopancreas to that in the stomach is similar for all categories except the 'very full' category.

Before analysing the distributions of krill in the feeding categories 'emptying or filling' and 'very full', the relation between the feeding category in which a krill was placed and the histological moult stage of that krill must be established (Table 4). The relatively

Table 4. Euphausia superba. Number of specimens classed as moulting (late pre-moult to early post-moult) or intermoult (late post-moult to early pre-moult) as a function of feeding category and hardness of exoskeleton. Values in parentheses: $\%$ of krill classed as immediate pre-moult, ecoysis or immediate post-moult

\begin{tabular}{|llcc|}
\hline $\begin{array}{l}\text { Feeding } \\
\text { category }\end{array}$ & $\begin{array}{c}\text { Exoskeleton } \\
\text { condition }\end{array}$ & $\begin{array}{c}\text { Moul- } \\
\text { ting }\end{array}$ & $\begin{array}{c}\text { Inter- } \\
\text { moult }\end{array}$ \\
\hline Empty & Hard & $26(100)$ & 0 \\
Emptying & Soft & $10(100)$ & 0 \\
or filling & Sard & $8(75)$ & 36 \\
Full & Hard & $4(100)$ & 0 \\
& Soft & $0(-)$ & 85 \\
Very full & Hard & $0(-)$ & 3 \\
& Soft & $0(-)$ & 0 \\
\hline
\end{tabular}

low numbers of krill analysed for moult stage precludes the use of the 17 or more stages of the moult cycle described by Buchholz (1982). Instead, krill are grouped into 2 broad categories, those in some stage of moulting and those in intermoult. The terms moulting and intermoult, therefore, represent not so much a strict histological moult stage but more a broad physiological classification. As expected, all of the krill in the 'empty' feeding category were directly involved in ecdysis and over $86 \%$ of the krill categorised as 'full' were in the intermoult phase. Krill that were 'emptying or filling' were mainly in the intermoult phase, although $25 \%$ were classed as moulting (of these three-quarters with a hard exoskeleton and all with a soft exoskeleton were in the ecdysis phase). All 3 of the 'very full' krill examined histologically were in the intermoult phase, with a hard exoskeleton (Table 4).

The relations between histological moult stage and the feeding categories 'emptying or filling' and 'very full' are not clear. This is partly the result of the broadness of the intermoult classification used and partly due to the small number of krill analysed. In the absence of a clear relation, hypotheses of a transitional phase between moulting and intermoult l'emptying or filling') and a pre-moult increase in food reserves to fuel post-moult hardening ('very full') are tested by examining the distributions of krill in these categories.

Krill classed as 'emptying or filling' are distributed significantly differently from expected values (time, $\mathrm{p} \ll 0.001 ;$ df $=5 ;$ depth, $\mathrm{p} \ll 0.001, \mathrm{df}=3, \mathrm{n}=1392$ ). There were more krill in this category caught in the period 1600 to $2000 \mathrm{~h}$ between 70 and $100 \mathrm{~m}$, in the period 2400 to $0400 \mathrm{~h}$ between 10 and $100 \mathrm{~m}$, and in the period 0400 to $0800 \mathrm{~h}$ at the surface. There were significantly fewer krill in this category caught at the surface at night. This contrasts with the very large rise in the total numbers of krill caught at the surface at night compared to the day (Morris \& Ricketts 1984, Morris et al. 1984).

Krill categorised as 'very full' also had a significantly different distribution from that expected on the basis of a random occurrence of feeding categories (time, $\mathrm{p}<0.001, \mathrm{df}=5$; depth, $\mathrm{p}<0.05, \mathrm{df}=3, \mathrm{n}=361$ ). The major contributors to this difference were an increase in the numbers of krill caught from 0800 to $1200 \mathrm{~h}$ below the thermocline and from 1200 to $1600 \mathrm{~h}$ below $100 \mathrm{~m}$.

The proposed relations between individuals in the feeding categories 'emptying or filling' and 'very full' and the moulting behaviour of krill (abstracted from Fig. 1) are shown diagrammatically in Fig. 2. Krill in the feeding category 'very full' occurred prior to or during the afternoon peak of moulting activity. After this peak of moulting activity there was an increase in the number of krill caught in the feeding category 'emptying or filling' (it is not known whether these krill were post-moult krill filling the alimentary tract or pre-moult krill emptying it). The night peak of moulting activity was followed by an increase in the numbers of krill caught in the emptying or filling' feeding category; these were most probably post-moult krill filling the alimentary tract. Krill categorised as 'emptying or filling' were also found in higher proportions than expected at the surface in the morning. These may be pre-moult krill emptying the alimentary tract prior to moulting at the surface during the day.

To emphasise the overall pattern of moulting in Euphausia superba the distributions of all krill assessed as in ecdysis (i.e. 'empty' or with a soft exoskeleton) or in some stage of moulting (i.e. 'emptying or filling' and 'very full') are pooled in Table 5. There is a significant difference (time, $p \ll 0.001$, df $=5$; depth, $\mathrm{p} \ll 0.001$, df $=3, \mathrm{n}=2839$ ) between observed and expected values. These differences are summarised in Fig. 3 in an overall generalisation of the moulting behaviour of krill off South Georgia. The previously used time compartments are combined into 3 periods: morning, afternoon and night. During the day, the number of krill caught at the surface 


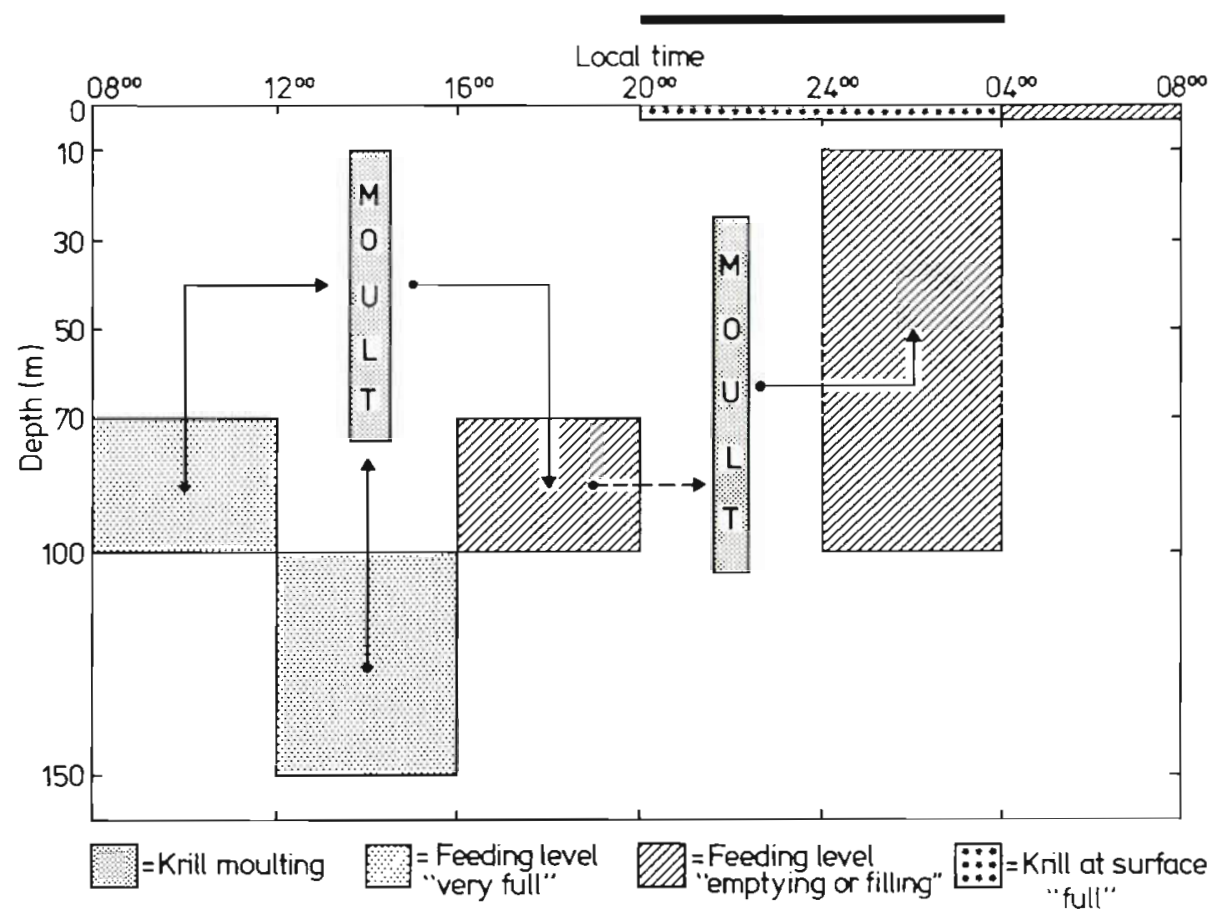

Fig. 2. Euphausia superba. Model of the relation of pre- and postmoult feeding levels to moulting as a function of water depth and time of day

was low (Morris \& Ricketts 1984) but the proportion of krill moulting in this layer was high: these krill were either in pre-moult (emptying the alimentary tract) in the morning or in ecdysis (empty/soft) in the afternoon. This is in marked contrast to the number of krill caught at night, which was high, whereas the number moulting was low. Moulting occurred throughout the rest of the water column during the morning, but at a lower level than expected. During the afternoon, moulting occurred primarily between 50 and $150 \mathrm{~m}$, whereas at night this depth range extended upwards to 10 to $150 \mathrm{~m}$.

\section{Integrated model of moulting and feeding}

Relations between the occurrence of Euphausia superba in swarms, their vertical distribution, feeding activity and moulting state as a function of time of day and depth are integrated (Fig. 4) from the model of feeding (Morris \& Ricketts 1984) and moulting (this paper) into a single model, which also includes the major trends in the environmental variables studied. Environmental variables are grouped into 2 classes: those that decrease below the thermocline (e.g. temperature and chlorophyll) and those that increase (e.g.

Table 5. Euphausia superba. Number of specimens categorised according to feeding state as moulting as a function of depth and time of day. Bar: darkness. Numbers in parentheses: expected values for the number of krill caught (pooled by all feeding categories)

\begin{tabular}{|lcccccccc}
\hline \multicolumn{1}{c}{$\begin{array}{c}\text { Depth range } \\
(\mathrm{m})\end{array}$} & $\begin{array}{c}\text { Local time } \\
08-12\end{array}$ & $12-16$ & $16-20$ & $20-24$ & $24-04$ & $04-08$ & Total \\
\hline Surface & 7 & 15 & 34 & 26 & 98 & 32 & 212 \\
$0-3$ & $(0)$ & $(4)$ & $(11)$ & $(151)$ & $(181)$ & $(15)$ & $(362)$ \\
Above thermocline & 39 & 191 & 60 & 152 & 226 & 97 & 765 \\
$10-50$ & $(93)$ & $(146)$ & $(91)$ & $(147)$ & $(181)$ & $(125)$ & $(783)$ \\
Below thermocline & 84 & 281 & 116 & 154 & 216 & 78 & 929 \\
70-100 & $(121)$ & $(140)$ & $(111)$ & $(127)$ & $(181)$ & $(153)$ & $(833)$ \\
Below 100 m & 52 & 117 & 221 & 213 & 192 & 138 & 933 \\
$100-150$ & $(103)$ & $(130)$ & $(151)$ & $(146)$ & $(181)$ & $(151)$ & $(862)$ \\
Total & 182 & 604 & 431 & 545 & 732 & 345 & 2839 \\
& $(317)$ & $(420)$ & $(364)$ & $(571)$ & $(724)$ & $(444)$ & $(2840)$ \\
\end{tabular}




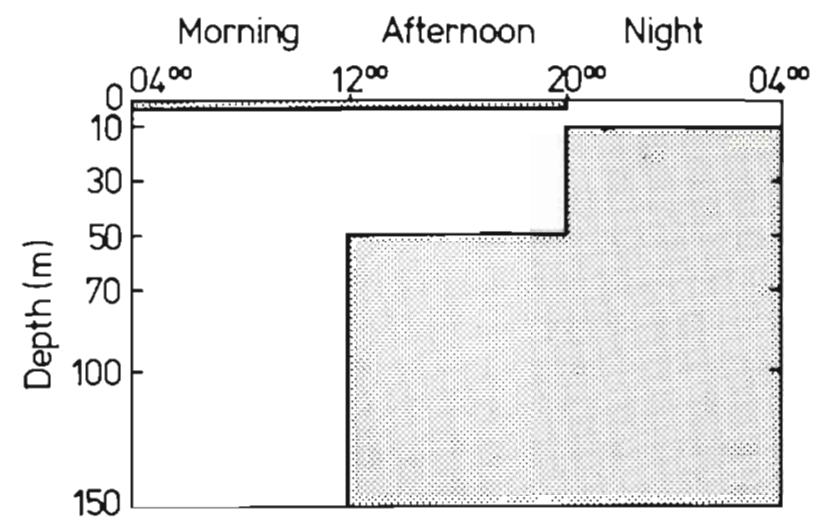

. $=$ Krill moulting

Fig. 3. Euphausia superba. Model of moulting behaviour of $\mathrm{krill}$ in the morning, afternoon and at night as a function of water depth

salinity and nutrients) (see Morris et al. 1984). The level of food in the alimentary tract remains constant with depth for the majority of the population. Depth of occurrence and shape of krill swarms are represented diagrammatically, the swarms occurring deeper and having a smaller horizontal chord in the day. The observed patterns of vertical migration are represented by the presence of krill at the surface at night, completing the pattern of large scale changes in krill density with time of day (Morris et al. 1984). Moulting behaviour is broadly divided into 2 phases of premoult, moult (including ecdysis) and a post-moult phase. The occurrence of post-moult krill having food in the alimentary tract at the same time as a soft exoskeleton (food present/soft) is distinguished in order to highlight the differences between the afternoon and night periods of moulting activity. The after- noon moulting period is characterised by a pre-moult build-up of food and post-moult krill that have empty alimentary tracts and hard exoskeletons. The night moulting period is characterised by the absence of a pre-moult food build-up and the absence of post-moult krill with empty alimentary tracts and hard exoskeletons. Those post-moult krill observed to have hard exoskeletons in the night moulting phase all had some food in their alimentary tracts but were not classed as 'full'.

\section{Variability in moulting frequency}

The total number of Euphausia superba observed to be in some stage of the moult part of the cycle during the $6 \mathrm{~d}$ study period amounted to $30 \%$ of the samples. The proportions of krill in intermoult, pre-moult and moult for each of the $6 \mathrm{~d}$ are given in Fig. 5. Although some moulting occurred during mornings, the percentages were very low. Moulting occurred on each day primarily in the 2 phases outlined in Fig. 4 . The afternoon moult occurs with the highest frequency for the afternoons of 2 Jan and 3 Jan while the night moult predominates on $4 \mathrm{Jan}$. The mean percentage of krill sampled that were directly involved with moulting during this period is $6.7 \% \mathrm{~d}^{-1}$, giving a theoretical intermoult period (IMP) of $14.9 \mathrm{~d}$ for an homogeneous population exhibiting random moulting.

There is a very large increase in the frequency of krill moulting following this period, with afternoon moults predominating. On $5 \mathrm{Jan}$, the proportion of krill moulting reaches $74 \%$ in the afternoon and $64 \%$ in the evening. These catches consisted primarily of krill described as empty/hard or empty/soft. The peaks in moulting that occur after $5 \mathrm{Jan}$ are derived from samples of fewer than 100 but the proportion of krill that
Fig. 4. Euphausia superba. Integrated model of krill swarming, feeding and moulting behaviour off South Georgia

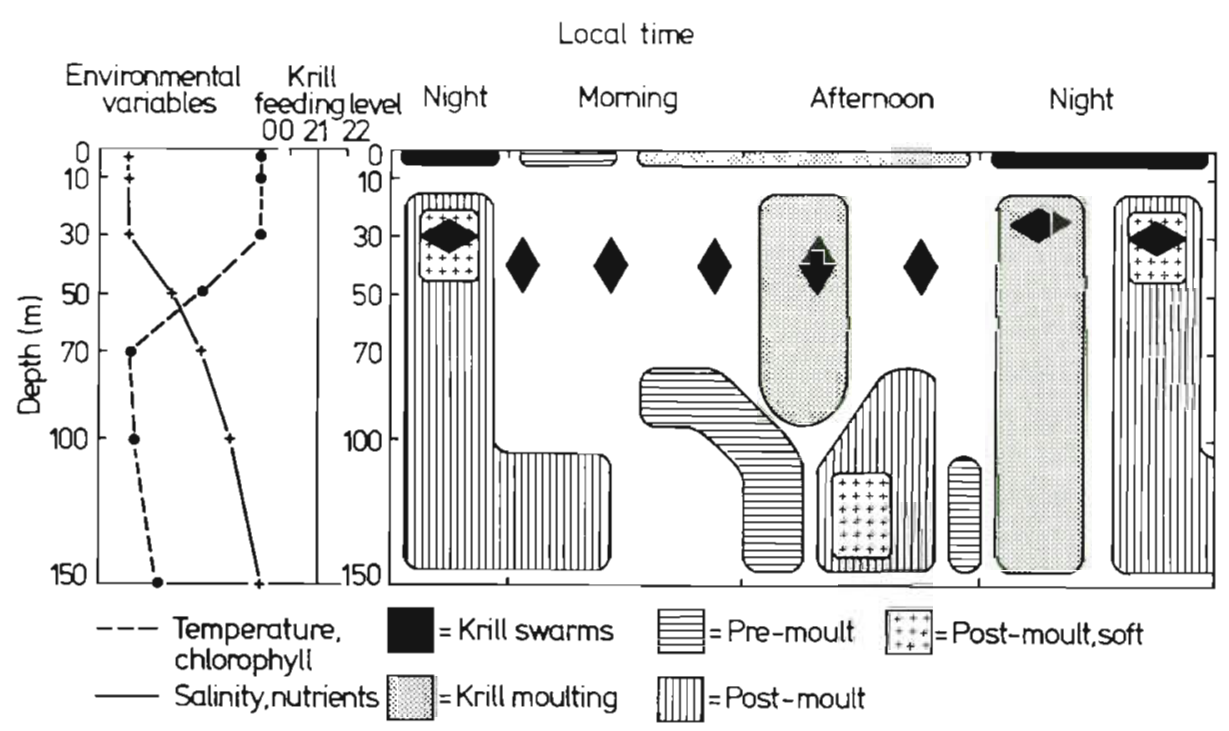




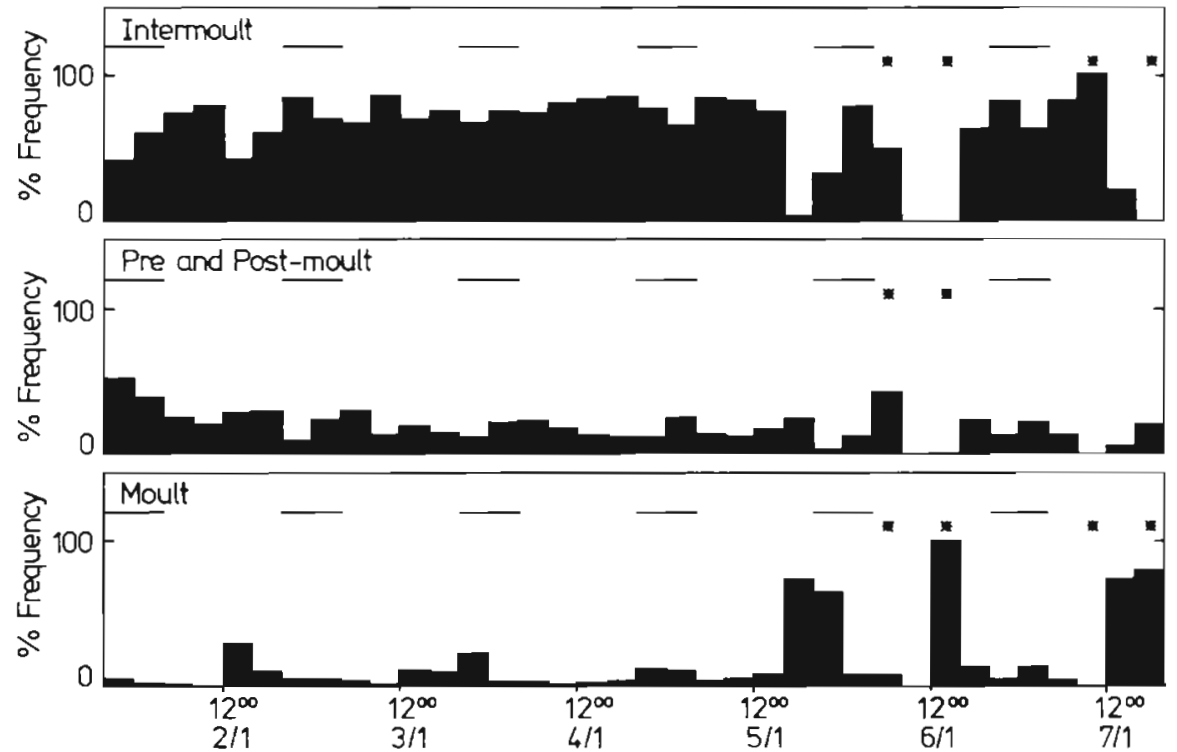

Fig. 5. Euphausia superba. Percentages of the population sampled in intermoult, pre-moult or moult for each of the $6 \mathrm{~d}$ of the study period. Data period as morning, afternoon and night and. by depth were moulting ranges from 74 to $100 \%$. The mean moulting frequency for this latter period is $37 \% \mathrm{~d}^{-1}$ (IMP $=2.7 \mathrm{~d}$ ). This gives a combined total of $100 \%$ of the population moulting in the $6 \mathrm{~d}$ study period if the population sampled was homogeneous.

\section{DISCUSSION}

\section{Field observations of moulting}

The existence of direct links between the cessation of feeding and the onset of moulting has already been established for Euphausia pacifica (Lasker 1966) and Meganyctiphanes norvegica (Fowler et al. 1971). Similarly, Buchholz (1982) and Morris \& Keck (1984) have further documented the connection between a soft exoskeleton and very recent moulting in E. superba. The data from the extensive field study of feeding in $E$. superba off South Georgia (Morris \& Ricketts 1984) has, by use of these links between feeding and moulting, allowed models of the ecology of moulting to be constructed which, because they are derived from field data, do not suffer from the drawbacks of laboratory studies (e.g. Morris \& Keck 1984). The resolution of the proposed models is, however, coarse because of the $4 \mathrm{~h}$ sampling interval and the limited numbers of krill analysed for histological moult stage.

In contrast to previous laboratory observations, which suggested that moulting in Euphausia superba occurs primarily at night (Murano et al. 1979, Morris \& Keck 1984), these field data demonstrate 2 peaks in moulting activity, 1 in the afternoon and 1 in the early night. It is suggested that the aftemoon peak of moulting is composed primarily of pre-moult ('very full') krill that then empty the alimentary tract and shed the exoskeleton. It appears that E. superba are able either to harden the exoskeleton prior to feeding or to recommence feeding before complete hardening of the exoskeleton occurs. These 2 post-moult phases both occur primarily below $100 \mathrm{~m}$ in the afternoon peak of moulting activity. It is unknown whether the hypothesised pre-moult feeding condition 'very full' is actually a mechanism for fuelling a post-moult hardening process when the alimentary tract remains empty.

The peak of moulting activity that occurred at night differed from that during the afternoon in several ways. There were no pre-moult 'very full' krill, although premoult krill (empty/hard) are present in the late afternoon. Ecdysis occurred throughout the water column, except at the surface where krill densities were very high at night. The nighttime post-moult phase was particularly characterised by the absence of krill with an empty alimentary tract and a hard exoskeleton; it consisted primarily of krill with a soft exoskeleton and food in the alimentary tract. These krill also occurred below the surface but above the thermocline, where the concentrations of chlorophyll in the water were highest (Morris et al. 1984). The post-moult phase during the night was also characterised by the occurrence of higher numbers of krill with a hard exoskeleton 'filling' the alimentary tract.

The changes in the vertical distribution of krill with soft exoskeletons between day and night indicate that light levels may affect moulting. In view, however, of the occurrence of moulting at the surface during the day and its absence at night, it seems likely that the density of krill (Morris et al. 1984) may also be of importance. These 2 observations may be reconciled if predation (with visual location of prey) and possibly 
cannibalism are important factors for moulting and post-moult krill that have a soft exoskeleton. There are few data on the occurrence of cannibalism in relation to moulting, but Hamner (1984) has reported visual observations of krill leaving 'schools' to moult or lay eggs (possibly as a method of avoiding other krill). Furthermore, the need to avoid cannibalism during moulting may be a contributory factor in the occurrence of synchronous moulting observed in the laboratory (Mackintosh 1967, Clarke 1976). Mackintosh (1967) also predicted the existence of synchronous moulting in the field from observations of catches of cast exoskeletons en masse (Station 514, near South Georgia, Discovery Station List, 1932). Net hauls of cast exoskeletons have also been observed by the author in late winter off South Georgia (Station JB04 1179). These data, plus the existence of several catches of krill dominated by empty/hard or empty/soft animals (personal observation; Fig. 5), indicate that synchronous moulting does indeed occur in the field and may be related to the avoidance of predation or cannibalism.

\section{Implications of the integrated model}

In their discussion of the relations between the proposed feeding model for Euphausia superba and the environment, Morris \& Ricketts (1984) and Morris et al. (1984) suggested that the fact that depth had no effect on the amount of plant pigment in the alimentary tract was possibly the result of a high turnover rate of chlorophyll in the stomach and hepatopancreas. If this is the reason, the rapid processing of ingested plant pigment would mean that the level of plant pigment in an animal is unlikely to be a good indicator of the amount of plant pigment passing through that animal. This proposal is now examined in more detail as it provides an explanation for the apparent absence in the integrated model of any environmental effects, such as chlorophyll concentration or temperature, on feeding acitivity. Data from the energy budget for $E$. superba constructed by Clarke \& Morris (1983) are combined with egestion rates given by Antezana et al. (1982) and the levels of chlorophyll found in krill off South Georgia (Morris \& Ricketts 1984). Published data are all for krill of approximately $1 \mathrm{~g}$ wet weight and these have been scaled linearly, for simplicity, to krill of $0.3 \mathrm{~g}$ wet weight to approximate krill in the population studied.

Clarke \& Morris (1983) indicate an energy requirement, off South Georgia, of about $5 \%$ of body weight per day for krill to sustain growth. This is equivalent, using their conversions, to a chlorophyll intake of $312 \mathrm{ng} \mathrm{h}^{-1}$. Antezana et al. (1982) give an egestion rate equivalent to $33 \mathrm{ng} \mathrm{h}^{-1}$ and a length of egested faeces of $1.7 \mathrm{~cm} \mathrm{~h}^{-1}$. These data can be combined with the ambient levels of chlorophyll in the water $(0.05$ to $1.0 \mu \mathrm{g} \mathrm{I}^{-1}$; Morris et al. 1984) and in the stomach (19 $\mathrm{ng}$ ) and hepatopancreas (38 $\mathrm{ng}$; Morris \& Ricketts 1984). To convert these quantities to a filtration rate, a nominal retention efficiency of $50 \%$ for the filter basket is used (McClatchie \& Boyd 1983, Morris 1984). The energy requirement, equivalent to $312 \mathrm{ng} \mathrm{h}^{-1}$ of chlorophyll, is combined with the egestion rate to estimate an ingestion rate of $335 \mathrm{ng} \mathrm{h}^{-1}$. This also provides an incidental estimate of the assimilation efficiency of krill ( $89 \%$ ), although this figure is likely to be high since the laboratory egestion rates are probably low (Clarke \& Morris 1983). The calculated ingestion rate requires filtration rates of 0.7 to $13.4 \mathrm{l} \mathrm{h}^{-1}$ for the range of chlorophyll concentrations encountered in the water column. Even the highest filtration rates are well within the capabilities of krill (Morris 1984) and the implication is that chlorophyll concentration, and hence depth, should not provide a barrier to the distribution of krill (see also Morris et al. 1984).

The data outlined above can be combined with the levels of plant pigment in the stomachs and hepatopancreata of krill off South Georgia to provide estimates of the turnover times for plant pigment in these organs. These times are a turnover in the level of plant pigment in the stomach of once every $3.4 \mathrm{~min}$ and once every $7.3 \mathrm{~min}$ for the hepatopancreas. In addition, a turnover time for the gut can be estimated from the rate of $1.7 \mathrm{~cm} \mathrm{~h}^{-1}$ for egestion of faecal strings for a $3 \mathrm{~cm}$ krill, $2 / 3$ of which consists of alimentary tract. This gives a rate for the egestion of a faecal string of once every $72 \mathrm{~min}$. These turnover times are rough estimates only, but indicate a turnover of the order of minutes for the stomach or hepatopancreas and of an hour for the gut. The high turnover times for the stomach and hepatopancreas fit well with the relative uniformity of low levels of chlorophyll found in krill that are actively feeding. The longer estimate for the turnover time of the gut is reflected in the wide range of gut fullness levels encountered (Morris \& Ricketts 1984). These rough estimates are of interest physiologically but they also provide insights into the requirements for the design of future studies of the feeding activity of Euphausia superba, both in the laboratory and the field. Also, the times taken both to empty and fill the alimentary tract are so short that it is likely that the pre-and post-moult feeding states observed are more the result of the physiological constraints of the moulting process than of any feeding limitations.

The field observations on the moulting of Euphausia superba summarised in the integrated model conflict with laboratory data that indicate krill moult primarily at night. The apparent links between the occurrence of 
moulting and post-moult behaviour, light levels and krill density require further investigation both in the laboratory and in the field. One particular aspect of this behaviour is noteworthy. Despite a difference in the pattern of vertical migration and swarming both Everson (1982) and Morris et al. (1984) report a marked migration of krill to the surface at night off South Georgia. This behaviour is, according to the model proposed, related neither to feeding nor moulting.

The percentage of the sample that was moulting on each of the $6 \mathrm{~d}$ of the study period indicates either that moulting in the population is non-random or that the sampling covered more than 1 population of krill. A preliminary analysis of the length frequency distributions of krill caught on each of the $6 \mathrm{~d}$ indicated that only one population was sampled (Clarke \& Morris 1983). The moulting behaviour, however, indicates that, either the whole population moulted in the study period, that moulting krill are caught more readily or that more than 1 'population' of krill was sampled. The last is the more likely as a pronounced shift in wind direction, accompanied by a reversal in the direction of tow along the haul track, occurred at the time that the proportion of moulting krill rose. Furthermore, whilst the calculated IMP of $14.9 \mathrm{~d}$ for 2 to $4 \mathrm{Jan}$ is of an appropriate length for krill off South Georgia (Clarke \& Morris 1983), the IMP for 5 to $7 \mathrm{Jan}$ ( $2.7 \mathrm{~d}$ ) is clearly too low. Thus, despite the similarities in length frequency and feeding behaviour, it seems likely that at least 2 populations were studied. Such a shift in population during the $6 \mathrm{~d}$ period is probably an inevitable result of utilising a geographic haul track to sample an animal that lives in an environment dominated by large- and small-scale currents.

\section{Perspectives}

A knowledge of the mechanisms underlying the interactions of feeding, moulting, swarming and vertical migration in Euphausia superba is of great importance to our overall understanding of krill biology. An early model linking feeding, swarming and vertical migration (Pavlov 1969) was tested off South Georgia (Morris et al. 1983) in a pilot study that formed the basis of an intensive sampling period, the results of which are summarised in this paper. Sampling was designed to maximise the amount of information collected on krill feeding activity to the limits of the logistic capability ( $6 \mathrm{~d}$ on station), equipment (the deployment of a multiple RMT 8 net) and available manpower (5.4 man months). In addition, the location of the patch of krill studied was determined during a $30 \mathrm{~d}$ acoustic and oceanographic survey around South Georgia and the patch itself was mapped over $3 \mathrm{~d}$ both before and after the study. Data analysis was also extensive, involving some $12 \mathrm{~h}$ of computer CPU time for the construction of the feeding models alone.

Despite this comprehensive approach, the proposed models of feeding activity, physiology and moulting are of limited value. An understanding of the overall behaviour of Euphausia superba off South Georgia has not emerged, although the importance of moulting in relation to feeding has been highlighted and modelled. The results have more importantly outlined the limitations of the available logistics effort, sampling equipment and experimental design and reinforced the prior requirement for a thorough understanding of the structure of krill patches and their relations with the environment.

Whilst laboratory studies of both feeding and moulting will, given the pelagic nature of krill, provide limited but necessary data (Clarke \& Morris 1983), further field studies of the physiological ecology of Euphausia superba are vital. It is essential that such studies take into account the homogeneity of the patch or population under study and the high turnover rates of food which require serial rather than discrete sampling.

Acknowledgements. I thank all members of the OBP team, A. Keck for assistance with the moult staging, Drs I. Everson and C. Ricketts and P. Ward for collaboration in constructing the models used for this synthesis, Drs A. Clarke and J. Mitton for critical evaluation of the manuscripts and Miss E. Bailey and Miss S. Norris for typing.

\section{LITERATURE CITED}

Antezana, T., Ray, K., Melo, C. (1982). Trophic behaviour of Euphausia superba Dana in laboratory conditions. Polar Biol. 1: $77-82$

Antezana, T., Ray, K. (1984). Feeding of Euphausia superbain a swarm north of Elephant Island. J. Crust. Biol. 4 (Suppl.): $26-38$

Buchholz, F. (1982). Drach's moult staging system adapted for euphausiids. Mar. Biol. 66: 301-305

Clarke, A. (1976). Some observations on krill (Euphausia superba Dana) maintained alive in the laboratory. Bull. Br. Antarct. Surv. 43: 111-118

Clarke, A., Morris, D. J. (1983). Towards an energy budget for krill; the physiology and biochemistry of Euphausia superba Dana. Polar Biol. 2: 69-86

Everson, I. (1982). Diurnal variations in mean volume of backscattering strength of an Antarctic krill (Euphausia superba) patch. J. Plankt. Res. 4: 155-162

Fowler, S. W. Small, L. F., Keckes, S. (1971). Effects of temperature and size on moulting of euphausiid crustaceans. Mar. Biol. 11: 45-51

Gubsch, G. (1979). Investigations on krill Euphausia superba Dana off South Orkneys and South Shetlands in 1979. ICES CM L 34: 1-12

Hamner, W M. (1984). Aspects of schooling in Euphausia superba. J. Crust. Biol. 4 (Suppl.): 19-25

Hamner, W. M., Hamner, P. P., Strand, S. W., Gilmer, R. W. 
(1983). Behaviour of Antarctic krill Euphausia superba: chemoreception, feeding, schooling and moulting. Science 220: 433-435

Ikeda, T., Nash, G. V., Thomas, P. G. (1984). An observation of discarded stomach with exoskeleton moult from Antarctic krill Euphausia superba Dana. Polar Biol. 3: 241-244

Kalinowski, J., Witek, Z. (1980). Diurnal vertical distribution and migration of krill swarms in the western Antarctic ICES CM L 49: 1-12

Kato, M., Segawa, S., Tanoue, E., Murano, M. (1982). Filtering and ingestion rates of the Antarctic krill, Euphausia superba Dana. Trans. Tokyo Univ. Fish. 5: 167-175

Kils, U. (1981). Swimming behaviour, swimming performance and energy balance of Antarctic krill Euphausia superba. BIOMASS Sci. Ser. 3: 1-233

Lasker, R. (1966). Feeding, growth and carbon utilisation of a euphausiid crustacean. J. Fish. Res. Bd Can. 23: 1291-1317

Mackintosh, N. A. (1967). Maintenance of living Euphausia superba and frequency of moults. Norsk. Hvalfangsttid 56: 97-102

Mauchline, J., Fisher, L. R. (1969). The biology of euphausiids. Adv. mar. Biol. 7: 1-454

McClatchie, G., Boyd, C. M. (1983). A morphological study of sieve efficiencies and mandibular surfaces in the Antarctic krill Euphausia superba. Can. J. Fish. aquat. Sci. 40: 955-967

Morris, D. J. (1984). Filtration rates in Euphausia superba: under or over estimates? J. Crust. Biol. 4 (Suppl.): 239-254

Morris, D. J., Keck, A. (1984). Preliminary studies of the time course of the moult cycle of Euphausia superba in the laboratory. Meeresforsch. 30: 94-100

Morris, D. J., Ricketts, C. (1984). Feeding of krill around South Georgia I: a model of feeding activity in relation to depth and time of day. Mar. Ecol. Prog. Ser. 16: 1-7

Morris, D. J., Ward, P., Clarke, A. (1983). Some aspects of feeding in the Antarctic krill Euphausia superba. Polar Biol. 2: 21-26

Morris, D. J., Everson, I., Ricketts, C., Ward, P. (1984). Feeding of krill around South Georgia II: relationships between feeding activity, environment and vertical distribution. Mar. Ecol. Prog. Ser. 20: 203-206

Murano, M., Segawa, S., Kato, M. (1979). Moult and growth of the Antarctic krill in the laboratory. Trans. Tokyo Univ. Fish. 3: 99-106

Pavlov, V. Ya. (1969). The feeding of krill and some features of its behaviour. Tr. Vses. Nauchno-Issled Inst. Morsk. Rybn. Khoz. Okeanogr 66: 207-222

This paper was submitted to the editor; it was accepted for printing on January 10,1984 